\title{
(En)gendering exposure: pregnant farmworkers and the inadequacy of pesticide notification
}

\author{
Madison Barbour ${ }^{1}$ \\ Julie Guthman \\ University of California, Santa Cruz, USA
}

\begin{abstract}
In 2015, the EPA (USA) announced its intention to strengthen farmworker protections against pesticide exposure to include information on the hazards of pesticide exposure during pregnancy and how to reduce takehome exposure. While the new Worker Protection Standard is a laudable and long-overdue effort to enhance farmworker safety, we argue that an informational approach is inadequate, particularly for the women farmworkers who are the focus of the expanded training content. It is particularly deficient given new epigenetic knowledge that suggests a greatly expanded temporal and spatial horizon between pesticide exposure and effect. At the same time it puts an additional moral burden on women farmworkers who are made responsible for protecting future populations. The article draws in part on 55 interviews we conducted with farmworkers as part of a larger project on fumigation use in California's strawberry industry. Analysis of these interviews sheds light on the practical fallacies of an information-oriented regulatory program when most farm workers feel that not working is the bigger risk. We found that farmworker men and women already recognized the potential dangers of pesticide exposure without additional notification, yet farmworker women felt even more limited in their ability to protect themselves from exposure at the workplace. Farmworkers who worked during their pregnancies felt particularly at risk. Since these enhanced protections do not address the sociocultural and eco-biological obstacles farmworker women face in protecting themselves and their future progeny from pesticide exposure, we suggest that they are primarily performative.
\end{abstract}

Keywords: Pesticide exposure, pesticide regulation, political ecology of the body, epigenetics, gender, responsibilization

\section{Résumé}

En 2015, l'EPA (États-Unis) a annoncé son intention de renforcer les mesures de protection des travailleurs agricoles contre l'exposition aux pesticides afin d'inclure des informations sur les dangers d'exposition aux pesticides pendant la grossesse et de réduire l'exposition à la maison. Bien que la nouvelle norme de protection des travailleurs soit un effort louable et attendu depuis longtemps pour améliorer la sécurité des ouvriers agricoles, nous soutenons qu'une approche informationnelle est inadéquate, en particulier pour les ouvrières agricoles. Ils sont au centre du contenu de formation élargi. L'approche est particulièrement déficiente compte tenu des nouvelles connaissances épigénétiques, qui suggèrent un horizon temporel et spatial considérablement élargi entre l'exposition aux pesticides et leur effet. Dans le même temps, cela impose un fardeau moral supplémentaire aux travailleuses agricoles qui sont chargées de protéger les populations futures. L'article s'appuie sur 55 entretiens que nous avons menés avec des ouvriers agricoles dans le cadre d'un projet plus large sur l'utilisation de la fumigation dans l'industrie de la fraise en Californie. L'analyse de ces entretiens met en lumière les erreurs pratiques d'un programme de réglementation axé sur l'information, alors que la plupart des travailleurs agricoles estiment que le fait de ne pas avoir d'emploi constitue un plus grand risque. Nous avons constaté que les ouvriers agricoles et les ouvrières agricoles reconnaissaient déjà les dangers potentiels de l'exposition aux pesticides sans notification supplémentaire, mais les ouvrières agricoles étaient encore plus limitées dans leur capacité à se protéger de l'exposition sur leur lieu de travail. Les travailleurs agricoles qui travaillaient pendant leur grossesse étaient particulièrement exposés. Les ouvrières agricoles doivent se

\footnotetext{
${ }^{1}$ Madison Barbour, student, University of California, Santa Cruz, USA. Email: mibarbou "at" ucsc.edu. Dr. Julie Guthman, Professor of Social Sciences, University of California Santa Cruz. Email: jguthman "at" ucsc.edu. Acknowledgments: We are grateful for the research assistance of Sandy Brown, Rachel Cypher, and Jean Larson in conducting interviews and Yajaira Chavez, and Savannah Coker in transcribing and coding interviews. We are also thankful for the usefully constructive comments of two anonymous reviewers. This work was supported by the US National Science Foundation, Award \# 1262064.
} 
protéger elles-mêmes et protéger leur future progéniture contre l'exposition aux pesticides, mais le programme de réglementation n'aborde pas les obstacles socioculturels et éco-biologiques auxquels elles sont confrontées. Il est donc essentiellement performatif.

Mots-clés: exposition aux pesticides, régulation des pesticides, écologie politique du corps, épigénétique, genre, responsabilisation

\section{Resumen}

En 2015, la EPA (Estados Unidos) anunció su intención de fortalecer las protecciones para los trabajadores agrícolas contra la exposición a pesticidas al incluir información sobre los riesgos a la exposición durante el embarazo y cómo reducir las exposiciones que llegan a casa. Mientras que la nueva Norma de Protección al Trabajador es un esfuerzo loable y ya con retraso para asegurar la seguridad de los trabajadores agrícolas, nosotros argumentamos que una aproximación informativa no es adecuada, especialmente para mujeres que trabajan en el campo y quienes son objetivo del contenido de una capacitación más amplia. Resulta particularmente deficiente dado que nueva información epigenética sugiere un enorme horizonte temporal y espacial entre la exposición al pesticida y el efecto. Al mismo tiempo, esta aproximación impone una carga moral adicional en trabajadoras agrícolas quienes son responsabilizadas de proteger futuras poblaciones. El artículo se basa, en parte, en 55 entrevistas que realizamos con trabajadores agrícolas como parte de un proyecto más amplio del uso de fumigación en la industria de la fresa en California. El análisis de estas entrevistas ilustra las falacias prácticas de un programa regulador basado en información, cuando la mayoría de los trabajadores agrícolas consideran que el peor riesgo es no trabajar. Encontramos que tanto hombres como mujeres que trabajan en el campo, ya reconocen los peligros potenciales de la exposición a los pesticidas sin más notificación, más aún, las mujeres se sienten aún más limitadas en su posibilidad de protegerse de la exposición en su trabajo. Mujeres que trabajaron durante su embarazo, se sienten especialmente en riesgo. Como estas protecciones mejoradas no señalan los obstáculos socio-culturales y eco-biológicos que las mujeres enfrentan al protegerse ellas y a su descendencia de la exposición al pesticida, sugerimos que son primordialmente performativas.

Palabras clave: exposición a pesticidas, regulación de pesticidas, ecología política del cuerpo, epigenética, género, responsabilización

\section{Introduction}

Farmworkers, who disproportionately bear the burdens of pesticide exposure from chemically intensive agricultural production regimes, have long been subject to the inadequacies of the regulatory frameworks designed to protect them. In an effort to rectify the inadequacies of existing pesticide protections for farmworkers, in 2015 the US Environmental Protection Agency (USEPA) released a new Worker Protection Standard (WPS) that would go into effect in January of 2017. Delayed in implementation by Scott Pruitt, the original Trump appointee to head the USEPA who intended to revisit the new standard, at the time of publication of this article, the WPS is back on track to go into effect, thanks to a lawsuit filed by several states. The new Worker Protection Standard focuses on enhancing access to pesticide safety information and improved explanation of pesticide hazards. Importantly, the new WPS extends access to pesticide information to all farmworkers, many of whom were excluded from federal right-to-know laws under the old Worker Protection Standard (Brennan et al. 2015). In addition, for the first time, the content requirements for mandated fieldworker pesticide safety training have been expanded to include information about the hazards of pesticide exposure during pregnancy, and information on how to reduce take-home exposure (EPA n.d.).

Requiring farmworkers to be informed of the hazards of pesticide exposure during pregnancy is a wellintentioned acknowledgement of the particular vulnerability of pregnant women to pesticide exposure. These efforts are laudable and long overdue. However, we contend that the EPA's efforts to strengthen the regulatory framework around farmworker protections may prove inadequate to enhancing farmworker safety, focused as such efforts are on information dissemination as a primary method to improve safety. Lack of information is generally not the primary obstacle to self-protection. An information-based approach is particularly inadequate in the case of the women farmworkers who are the focus of the expanded training content about on-farm pesticide use and pregnancy health, and yet have little means to protect themselves or their future progeny. 
In this article we review the political-structural and bio-ecological conditions that make the new Worker Protection Standard insufficient, especially for farmworker women. We also discuss the inadequacy and misguidedness of informational approaches, which assume a lack of knowledge, to addressing health problems among marginalized populations. We thus draw on three themes in political ecology - one about the structural conditions that create ill health, one about the interaction of external conditions and bodily ecologies (i.e., political ecology of the body), and one about the limits of apolitical, individualized approaches to addressing environmental problems. To further our case, we draw on interviews we conducted with 55 farmworkers regarding their experience with pesticide exposures, as part of a larger project on the biopolitics of soil fumigant regulation in California's strawberry industry. Analysis of these interviews sheds light on the practical fallacies of an information-oriented regulatory program when most farm workers feel that losing their livelihood is a bigger risk. Confirming the findings of other studies exploring farmworker perceptions of pesticide exposure, we also found gendered differences on perspectives in pesticide use. Farmworker men and women both recognized the potential dangers pesticide exposure posed to themselves and their families (even without additional notification), but farmworker women felt even more limited in their ability to protect themselves from exposure at the workplace, and farmworkers who worked during their pregnancies felt particularly at risk. Since these enhanced protections do not address the socio-cultural and eco-biological obstacles farmworker women face in protecting themselves and their future progeny from pesticide exposure, we suggest that they are primarily performative, despite the best efforts of those who have championed these protections.

\section{Socio-cultural conditions of insufficient pesticide protection for farmworkers}

A robust literature in the political ecology of health has focused on the external, political and structural conditions that make certain populations vulnerable to disease (Hausermann et al. 2012; King 2010). In parallel with this literature, a pesticide-concerned environmental justice literature has focused on structural and political vulnerabilities that make certain populations more likely to be exposed to environmental health hazards (Harrison 2008; Pulido 1996; Wargo 2009). With an eye toward the Worker Protection Standard, here we focus on these structural and political vulnerabilities, as well as the cultural conditions that lead to disproportionate exposure.

Historically, the regulatory agencies charged with protecting farmworkers have not sufficiently acknowledged the health impacts of occupational pesticide use on farmworkers, particularly fieldworkers (Guthman and Brown 2016; Harrison 2006, 2008). Pesticide use was discursively framed as an environmental issue, and farmworkers' concerns about pesticides as a workplace health and safety problem have long been marginalized in public discourse (Pulido and Pena 1998). Although the United Farm Worker Union's 19651971 campaign successfully raised public consciousness about the human health impacts of agricultural pesticides and made limited gains in securing added protections for agricultural workers in union contracts (Pulido 1996), farmworkers were excluded from federal legislation regulating occupational exposure to toxic hazards until the 1974 passage of the USEPA's Worker Protection Standard. This initial standard provided only minimal protections, however. It mandated pesticide safety training for farmworkers every five years and established limits on reentering a field after pesticide application. A testament to the difficulty of implementing proficient worker protections, even these nominal standards were vehemently contested by growers (Pulido 1996). A 1992 update to the standard created a new regulatory framework for protecting farmworkers from pesticide exposure. The updated standard mandated safety training, notification of pesticide application, provision of personal protective equipment and restrictions on re-entering recently treated fields.

The introduction and improvements to the Worker Protection Standard, while significant, did not fundamentally change the dynamics of farmworker protections in the state, and the use of highly toxic chemicals in ways that allow for significant exposures to agricultural workers and the surrounding community continued (Harrison 2008, 2011; Nash 2004, 2006). Evidence suggests that agricultural employers continued to exploit the marginality of their workforce to violate routinely the existing labor laws and pesticide use regulations with limited consequences (Harrison 2008). The 2015 standard, which focuses on strengthening the existing protective measures, encounters the same limitations to its efficacy as its previous iterations. Lax, decentralized and highly uneven enforcement continues to severely undermine the efficacy of the WPS as a protective measure, and unlike OSHA right-to-know laws, the EPA WPS does not protect worker 
confidentiality when reporting a pesticide use violation (Brennan et al. 2015). Given that a main obstacle to worker reporting of pesticide-induced illness and use violations is fear of deportation or employer retaliation, this constitutes a major obstacle to ensuring farmworker health and safety.

U.S immigration policy is a key factor contributing to farmworkers' disproportionate exposure to pesticides. Estimates for 2013 suggest that approximately half of the nation's agricultural workforce are unauthorized (NAWS 2013). Scholars have observed that the political marginalization of agricultural workers has allowed risky pesticide use practices to become an industry norm (Harrison 2011, 2006; Holmes 2013; Nash 2004). Importantly, as Willen (2007) observes, the structural vulnerability experienced by unauthorized migrants does not necessarily result from the fact of their lack of legal status-rather, it is the social, political and historical context in which this precarious legal status is embedded that determine the ways unauthorized status affects the lived experiences of unauthorized migrants. In the U.S, lack of citizenship, widespread antiimmigrant sentiment and the constant threat of deportation have converged to create an 'invisible' workforce of migrant laborers that has historically had limited success in contesting pesticide exposure (Harrison 2011; Mitchell 2007). Since the mid-1990s and the suite of border control operations enacted under President Bill Clinton, the political vulnerabilities that characterize the position of the state's agricultural workforce have only deepened as heightened border militarization, increased enforcement of domestic immigration policy and the growing virulence of anti-immigrant sentiment has furthered the marginalization of foreign migrants without citizenship, so that the distribution of occupational harm falls heaviest on unauthorized, indigenous workers (Brownell 2001; Cartwright 2011; Chavez 2013; Harrison and Lloyd 2012; Holmes 2013; Nevins 2001).

For the agricultural industry, however, the exposure of fieldworkers to toxic pesticides is a contested problem (Harrison 2006). The industry, driven by imperatives to maintain access to highly toxic yet effective chemical inputs, has successfully campaigned to frame the problem of pesticide exposure as characterized by 'incidents' of improper product use rather than as a frequent outcome of a pesticide-intensive industry with many regulations but comparatively lax enforcement (Harrison 2011, 2006; Saxton 2015). The problem of exposure is thus reduced to isolated incidents of 'bad farmers' who did not follow the rules, even though significant exposures can still occur when pesticides are applied according to the label (Harrison 2006). Narratives that posit the problem of exposure incidents as the fault of 'bad farmers' also obscure the ways in which the logics of capitalist agricultural production processes render some bodies disposable, and therefore vulnerable. Scholars who theorize racial capitalism highlight how the logic of capitalist accumulation relies on the production of inequalities among social groups that the logic of racism secures (Melamed 2015: Pulido 2017). Racialized bodies, valued for their labor, are otherwise rendered disposable, often due to the existence of surplus populations (McIntyre and Nast 2011; Yates 2011). In the case of environmental injustices, racially devalued bodies can operate as 'sinks' where pollution is deposited, such that capitalism is restructuring not only nature, but human bodies at the cellular level - one of the ways that the socio-cultural becomes ecobiological (Pulido 2017: 529). In other words, it is not only immigration policy and the precarious legal status of farmworkers that makes for their vulnerability to pesticide exposure, but the racist logics embedded in capitalism itself that renders certain bodies vulnerable and disposable.

The sociopolitical contexts in which they live and work structures farmworkers' (and farmers') decisions to engage in the use of personal protective equipment, and often this means that those working with pesticides do not follow these and other self-protective practices designed to protect themselves from pesticide exposure in the fields. Galt (2013) suggests that pesticide applicators eschew protective equipment due to "complex subjectivities" that are shaped by conditions that go beyond a lack of information or economic necessity, including a political economy of agricultural production that encourages bodily sacrifice to bolster productivity, a finding also highlighted by Horton (2016). For example, they might choose not to wear protective gear because its use increases the amount of time it takes to treat a field (p. 347). Berry workers face additional constraints on their ability to use protective equipment that greater knowledge of pesticide hazards and protective gear are unlikely to remedy. In his embedded ethnographic account of migrant berry workers in the United States, medical anthropologist Holmes (2013) describes some of the conditions affecting workers' choices to engage in risky pesticide safety behaviors. For berry harvest workers, piece-rates, which reward those who can pick the highest volumes efficiently, are the industry norm in compensation, encouraging workers to exert their bodies to the fullest extent to make the most income for the short duration of their 
seasonal employment. To achieve this, workers will eschew the use of gloves to protect their hands from chemical residues as they harvest, as these gloves impede the efficiency of harvesting by their accounts. To maximize their time in the fields, they may also eat in the fields without washing their hands. The need to make the most of their temporary income and the logics of piece-rate compensation encourage workers to sacrifice their bodies and health for the modicum of greater financial stability offered by a strong harvest (Elmore and Arcury 2001; Holmes 2013; Snipes et al. 2009). In writing about heat stroke and kidney disease among farmworkers, Horton (2016) makes an additional point: farmworkers are highly reluctant to drink water or ask for shade breaks, to keep the pace of production up. This is a matter of performing strength and trying to end the work day before the worst of heat sets in.

Further undermining the industry's notion of the safety of pesticide use are studies documenting the inadequacy of personal protective equipment as protection from health-damaging exposures (Flocks et al. 2012; Holmes 2013; Salvatore et al. 2008). Even if all workers were to follow protective protocols, evidence does not suggest that such practices would be enough to protect them and their families from the hazards of exposure. One study of strawberry fieldworkers in Monterey County found that participants had disproportionately high levels of organophosphate pesticide metabolites despite the use of self-protective behaviors like hand-washing, wearing gloves and protective clothing, and washing work clothes (Salvatore et al. 2008). Calvert et al. (2008), in an examination of reported pesticide poisonings of farmworkers from 1998 to 2005 , found that in $30 \%$ of acute poisoning cases, all pesticide labeling requirements had been adhered to. Even when growers and workers follow the mandated worker protection protocols, health-damaging exposures still occur, despite the insistence of the industry and the EPA that using products according to the label ensures safety. In short, the existing literature suggests that workers do not always use protective equipment and that even when they do exposure occurs despite its use.

Although scholars have noted the way that the political neglect and subsequent disproportionate exposures that farmworkers experience are distributed unevenly along workplace hierarchies structured by ethnicity and citizenship status, they have given notably less attention to the ways in which the distribution of this harm is gendered. Other scholars, however, have documented that women farmworkers are concentrated in the lowest-paying farm jobs and are neglected for promotion, and are frequently subject to gendered harassment at work and denied benefits offered to men (London et al. 2002; Thomas 1992; Waugh 2010). Then there is the well-known problem of working women's "double day", as they return home from earning income and are expected to meet the additional (gendered) cultural expectations of responsibility for family care. Authors have also examined the widespread problems of sexual assault and inadequate reproductive healthcare for farmworker women (Galarneau 2013; Waugh 2010). If gender, like citizenship and ethnic status, structures the farm labor hierarchy, then it is surely a salient dimension of farmworker vulnerability to occupational health and safety violations. It is unclear, therefore, that the new standard will fundamentally alter the socio-cultural conditions of farmworker pesticide exposure, especially for women.

\section{Pesticides, epigenetics and the political ecology of the body}

While much environmental justice and political ecology of health literature has focused on the external, structural conditions that determine farmworker vulnerability to pesticide exposure and its negative health impacts, a growing literature in the political ecology of the body has suggested that the body must be examined as an integral part of the environment in question and that emphasis should be placed on the way external conditions interact with the biophysical, internal and affective workings of the body to produce vulnerable bodily ecologies (Carney 2014; Guthman and Mansfield 2013; Hayes Conroy and Hayes Conroy 2013; Jackson and Neely 2015; Neely 2015; Saxton 2015). As described by environmental historian Linda Nash (2004), histories of exposure, inadequate health care, and other forms of neglect have combined with external factors to produce embodied vulnerabilities for farmworkers.

The science of environmental epigenetics is providing new insights as to how such external conditions and ecologies become embodied vulnerabilities (Guthman and Mansfield 2013; Holliday 2006). According to epigenetic theories, various exposures, stresses, and nutritive deficiencies can alter cellular environments in ways that affect phenotype without altering the underlying DNA sequence, causing a range of teratogenic, reproductive and neurodevelopmental disorders. Moreover, many of these changes in gene expression induced 
by environmental agents appear heritable, even across multiple generations, meaning the health effects of toxic exposure and other health insults are intergenerational (Crews and McLachlan 2006; Holliday 2006; Jablonka and Lamb 2002; Thayer and Kuzawa 2011). Research has also shown that low-dose exposure during critical periods of development, such as during gestation, can have greater negative health consequences than acute exposures at later times (Gore et al. 2006). In keeping with these theories, a major longitudinal birth cohort study in California's Salinas Valley (CHAMACOS) has found a variety of functional and neuro-developmental issues from mothers exposed to various pesticides (Castorina et al. 2003; Eskenazi et al. 2003; Young et al. 2005).

One problem is that the risk assessment models that determine acceptable exposure levels for pesticide regulations, and thus are embedded in pesticide notification requirements, are based on a toxicological approach that has not fully incorporated the insights of epigenetics (Krimsky 2000). Indeed, as Krimsky and others point out, models of risk assessment are generally based on linear dose response curve ("dose makes the poison") and fail to account for cumulative and interactive exposures - or the general stochasticity of epigenetic mechanisms (Calabrese and Baldwin 2003; Faulk and Dolinoy 2011; Hayes 2001; Wargo 2009). What constitutes an 'acceptable' exposure, or the levels of exposure at which adverse health outcomes are not expected to occur, is very difficult to determine (Gore et al. 2006; Guthman and Mansfield 2013; Krimsky 2000; Langston 2010).

The intergenerational and delayed health effects of epigenetic change further complicates some of the core assumptions of risk assessment models which assume immediate and demonstrable association between exposure and harm. In epigenetic models, the spatial and temporal relationship between exposure and effect is significantly attenuated, making definitive proof of harm virtually unattainable for a migrant population (Nash 2004). Given these complexities, along with the variety of factors that can induce epigenetic change—stress, levels of early-life nurture and nutrition, and the cumulative interaction of these changes-the ways in which pesticides come to damage farmworker bodies and endanger farmworker women's reproductive health are easily obscured. Nevertheless, pregnant farmworkers must work within the context of a protective framework that is based on an increasingly dated paradigm of acceptable exposure, making any protocols and protective measures designated by the WPS or pesticide use regulations inherently unreliable.

The changes wrought by epigenetic exposure in industrial agriculture may be examples of the ways that racial capitalism transforms bodies at the cellular level (Pulido 2017). That epigenetic changes may be cumulative in their effect suggests that environmental exposures layer onto one another and produce synergistic effects that result in the most serious health outcomes (Diamanti-Kandarakis et al. 2009; Kortenkamp 2007; $\mathrm{Mu}$ and Leblanc 2004). Farmworker women contend not only with the health impacts of pesticide exposure, but with high levels of stress, food insecurity, and a host of other health insults and environmental injustices that disproportionately affect their reproductive health and predispose their progeny to the most negative outcomes of toxic environmental exposures.

Epigenetic pathways are just some of the ways that farmworker women's political and social vulnerability translates into biological vulnerability for themselves and their future progeny, especially in relation to pesticide exposure. Galarneau (2013) observes how a common condition on farms, lack of adequate bathroom facilities, can facilitate the incidence of infections in women that have dangerous implications for pregnancy. Back-bending labor (like strawberry harvesting) and heat, as well as the psychosocial stresses of 'illegality', workplace harassment and poverty can heighten the risks associated with the already precarious pregnancies of farmworker women. Other scholars have noted women's greater vulnerability to pesticiderelated illness and injury on the farm and that women's concentration in low paying field work jobs, including weeding and picking, puts them at the greater risk for frequent, low-dose exposure from contact with plant residues (Kasner et al. 2012; Nyantakyi-Frimpong et al. 2016). In addition, men's predominance in the agricultural workforce allow men to establish the prevailing work ethic in the field according to masculine norms of hard work and bodily resilience to hazard, ideals which discourage the use of protective practices that impede the efficacy of work and the contestation of pesticide exposure or safety violations (Horton 2016).

The few studies on farmworker perspectives on pesticide exposure that take gender to be an important factor have found that farmworker women sense their own heightened vulnerability relative to their male counterparts: they generally perceive greater risks in pesticide use, and pregnant farmworkers express the belief 
that no protective equipment or safety practice is enough to meaningfully protect their fetus from occupational pesticide exposure (Cabrera and Leckie 2009; Flocks et al. 2012). The high-risk pregnancies of farmworker women should thus be understood in this context, as an embodied vulnerability arising from a syndemic of health insults that interact to produce vulnerable bodily ecologies (Gravlee 2009; Horton 2016; Saxton 2015).

\section{Informational approaches and apolitical ecologies}

Political ecology has long been critical of apolitical approaches to environmental problem-solving such as individual choice models that imagine self-actualized and non-constrained citizens as being able to choose behaviors that minimize their own exposures (Robbins 2007). As it happens, several scholars have written on the limits of educational approaches to address problems like food insecurity, oral hygiene, and dietary health among Latino immigrant populations. Such approaches, they argue, suggest that differential health outcomes are the result of poor individual choices and a failure to take responsibility for one's well-being rather than the result of structural inequalities that present barriers to good health (Greenhalgh and Carney 2014; Horton and Barker 2009; Minkoff-Zern and Carney 2015). By focusing on the role of personal responsibility and individual choices in health outcomes, these discourses work to marginalize further the subjects of those inequalities, as poor health measures among these populations become indicative of their failure to take personal responsibility for their well-being and behave as good 'biocitizens' (Greenhalgh and Carney 2014; also see Guthman 2011). Pushing back against the assumptions of ignorance inherent in informational approaches to addressing health problems among marginalized communities, some scholars have shown how the targets of these campaigns often already possess significant knowledge about the problems they are ostensibly ignorant of (Greenhalgh and Carney 2014; Minkoff-Zern 2014). Minkoff-Zern (2014), for example, discusses how farmworkers are adept at developing strategies for coping with the problem of food insecurity, for example by cultivating home gardens, which demonstrate their existing knowledge and ability to construct healthy livelihoods. Greenhalgh and Carney (2014) offer related insights in an article that demonstrates, contrary to the assumptions of antiobesity campaigns, that Latinos are already well-versed in the types of diet and exercise regimes thought to contribute to healthy weight. In a similar vein, Castaneda and Zavella (2003: 127), writing about migrant Mexicana farmworkers' heightened vulnerability to sexually transmitted diseases, observe that Mexicana farmworkers "construct complex local knowledges and practices regarding sexuality", discourses that are shaped by their lived experiences in the social, political and economic contexts which place them at heightened risk of experiencing sexual health problems. Taken together, these studies suggest that informational approaches to addressing health disparities among marginalized populations ignore the existing knowledges possessed by these groups and obscure the role of structural inequalities in producing the differential health outcomes they seek to address.

Guaranteeing access to information about occupational toxins is no trivial matter for farmworkers, who have historically been excluded from worker right-to-know legislation. Right-to-know has been a rallying cry for environmental justice battles where toxicity is hidden (Brown 2007; Harrison 2011). Advocacy groups recruited farmworkers to submit comments to the EPA's proposed rule, and the importance of knowing what pesticides are used in the workplace and their potential health effects was a salient theme in many workers' submissions (Brennan et al. 2015). Nevertheless, right to know legislation not only assumes a lack of knowledge about environmental hazards; it also depends on the juridical ability to act on that knowledge. Again, farmworkers, as a largely unauthorized population, generally lack the juridical standing necessary to report violations without legitimate fear of retaliation by employers or the legal system. Moreover, as with other health risks, there is evidence that farmworkers already possess a significant lay knowledge about the hazards of pesticide exposure (Flocks et al. 2007; Cabrera and Leckie 2009; Galt 2013).

Somewhat separately, political ecologists have critiqued information-oriented approaches for their disciplining effects, especially as they relate to pregnant women and potentially pregnant women. Indeed, these scholars suggest that the new science of epigenetics is complicit in the disciplining of women's bodies. For, as Mansfield and Guthman (2015) point out, epigenetics has also operated as a normalizing discourse. It takes altered phenotypes as evidence of abnormalities that ought not to occur. Insofar as disproportionate exposure due to racialized hierarchies manifest in minor differences in, say, IQ or head circumference, epigenetic analysis can effectively pathologize black and brown bodies. Furthermore, despite that epigenetic science 
suggests that potential exposures are ubiquitous, thereby diffusing responsibility away from the individual and into the wider environment, epigenetic knowledge has been used to encourage individuals to control behaviors through which they are exposed to the environment (Mansfield and Guthman (2015: 15). Mainly, though, since the uterine environment is the site and pregnancy the temporality in which epigenetic exposure most visibly takes place, the discourse puts disproportionate responsibility on (pre-menopausal) women - those who are pregnant or may someday become pregnant - to manage population health (Mansfield 2012; Mansfield and Guthman 2015), even though sperm may be affected by environmental exposures as well. In these ways, epigenetic science intensifies the gendered disciplinary mechanisms already endemic to information based approaches to pesticide safety. As such, informational approaches regarding pesticide exposure during pregnancy make farmworker women feel more responsible, regardless of whether they are able to avoid the exposure. As we show in what follows, informational approaches are indeed fraught when aimed at pregnant farmworker women. The women we interviewed are already aware of the hazards pesticide exposure poses to their pregnancies, experience additional gendered responsibility for protecting future progeny, and yet face additional, gendered obstacles to self-protection that more information about pesticide safety simply cannot remedy.

\section{A study of farmworker perspectives on pesticide exposure}

In 2013-2014, we conducted semi-structured, qualitative interviews with 55 strawberry farmworkers in Ventura, Santa Barbara, Santa Cruz and Monterey counties. These counties represent the four major strawberry fruit-growing regions in California. The California strawberry industry entails one of the most lucrative yet chemically intensive crop production regimes, with some of the highest weight of pesticide applied and financial returns per acre of any crop grown in the state (Bolda et al. 2010; Kegley et al. 2000). These data were collected as part of a wider project investigating the biopolitics of alternatives to methyl bromide, a widely used soil fumigant in the strawberry industry, in the wake of the chemical's protracted phase out under the Montreal Protocol. Originally, the object of including farmworkers in the research was to gain insight into farmworker perspectives on the use of controversial and highly toxic soil fumigants such as methyl iodide. However, during the interview process new points of interest emerged, as worker stories indicated the desire to discuss the realities of pesticide exposure more generally rather than focus on a particular chemical class and its harms. Additionally, the interviews with many women who worked during their pregnancies, and the existing dearth of research that addresses the particular struggles of farmworker women, suggested to us that more attention needed to be given to the gendered aspects of pesticide exposure. Together, these findings shed light on the limits of information-based strategies as embedded in the new WPS.

Research participants for the study were recruited from residential farmworker communities. Subjects were eligible to participate if they currently or had previously worked in the strawberry industry performing fieldwork. Informed consent was solicited from all subjects before the interview process began, and subjects were compensated US\$20 for their participation in the study. Owing to the difficulty of accessing a 'hidden' population for the purposes of research, the data were collected by convenience sample, with the result that the demographic characteristics of this sample are not wholly representative of the strawberry field workforce writ large. Our sample included more women than is typical of the strawberry workforce; the sample was comprised of $45 \%$ women, whereas the state's agricultural workforce on the whole is $72 \%$ male (NAWS 2013). However, because the object of this analysis is to elucidate how gender matters in farmworkers' perception of pesticide exposure, the roughly even divide between men and women in our sample proved useful. Additionally, Spanish was not the first language of interviewees in every case. This study included interviews of six indigenous farmworkers whose first languages were Mixteco and Zapateco. Language barriers may have limited our study, but they almost certainly pose a significant obstacle to implementation of existing worker protection standards, which rely on effectively communicating pesticide hazards and safety information to workers. These dynamics are not explored in this analysis, but see Arcury et al. (2010) for a discussion of these issues.

Interviews were conducted by a postdoctoral fellow and a graduate student researcher fluent in Spanish and trained in qualitative social science research methods. An undergraduate researcher conducted the interviews in Ventura County, with the help of a translator. Interviews consistently included questions about workers' experiences with pesticide exposure, their perceived risk from exposure to pesticides, and for women, 
whether they had ever worked in the fields during a pregnancy. The semi-structured nature of the interviews allowed for subjects to expand upon their answers and provide detailed stories, generating a range of themes. With the consent of research subjects, interviews were recorded for later transcription. The content of interviews were then translated into English by a fluent speaker to allow for coding of the data with the assistance of NVivo, a qualitative data analysis software. Developing the relevant codes and organizing the data into framework matrices allowed us to distill the themes upon which this analysis is based.

Analysis of worker interviews are supplemented by data from informational hearings held by the California legislature on the approval of methyl iodide for commercial agricultural use. In the debates over the chemical's adoption, the vulnerability of pregnant farmworkers and their fetuses to the chemical's reproductive and developmental toxicity were deployed in arguments against the approval of methyl iodide. These data reflect the experiences of farmworkers and their communities with the reproductive and developmental health impacts of pesticide exposure, and speak to the failings of the worker protective and pesticide regulatory frameworks as they are currently structured.

\section{6. "Although we know the risks, we have to work"}

When the use of highly toxic chemicals are critical to robust harvests, debates around farmworker exposure between farmworker advocates and industry representatives tend to align around a discursive dichotomy of lives (health) vs. livelihoods (wages). But these oppositions are elided when wage work is arguably as necessary to an even marginal standard of well-being as maintaining physical health (Guthman 2016). Enduring dangerous and frequent exposures, workers sacrifice longevity and risk health problems or a life cut short. In the case of pregnant women, potential mothers are put in the impossible choice of weighing not only their lives, but those of their future children. But without wages, it is impossible to maintain a life in which one may cultivate 'health.' Workers consciously navigate this paradox, and their comments suggest that forgoing work is perceived as a greater threat to life than the daily injustice of pesticide exposure:

We live in the campo, so that is how it is; we work with the chemicals, we live surrounded by the chemicals...We have to live, so we become accustomed to it. After this it is in God's hands. What are we going to do? We have to work.

Although we know the risks, we have to work. This is the life of an immigrant, and of the worker of the campo.

Our interviews with farmworkers additionally suggest the greatest obstacles to worker protection and reducing pesticide exposure have little to do with a lack of information on their part. While they may not know the specific names or effects of the chemicals used on the farm, they generally recognized the health hazards associated with pesticides, and many reported direct or indirect experience of pesticide-related illness. Workers stressed the importance of knowing the names and specific health effects of the chemicals they work with, and when and where they are applied, but their comments depict a workplace structured by power dynamics that would strictly limit their ability to actually use this information. In interviews, workers frequently expressed a sense of pessimism and hopelessness about occupational pesticide exposure and illness:

The big problem for us is that we all know we are being exposed, but there's nothing we can do about it.

It would be better if I were to work without pesticides, but that is how it is. What are we going to do about it?

But I think that the mayordomos have techniques so that the people do their work, more than anything...so that they win....At the end, you realize that the trabajador will always lose. In one or two years, when there is no work, 'bye-bye.' 
This sense of hopelessness in contesting workplace exposure is rooted in the multiple injustices that characterize the farm labor hierarchy and prevent workers from exercising self-advocacy and other forms of resistance at work (Sexsmith 2016; Holmes 2013). The workers we interviewed expressed that they felt unable to discuss incidents of exposure with supervisors or employers, explaining that "complaining about allergies or chemical reactions would mean they wouldn't ask them back" and that exposure is "the sort of thing one can't complain about." Workers were asked whether they ever discussed concerns about pesticide exposure with their employers or refused to re-enter a recently treated field, and only one woman reported refusing reentry due to safety concerns, and she noted that she felt emboldened to do so because of her affiliation with the United Farm Workers union. These workers were not only well aware that self-advocacy could cost them their job, but that those who lacked citizenship were rightfully fearful of retaliation ("those who don't have papers have fear").

These pessimistic perspectives are supported by evidence that suggests existing protective measures, such as restrictions on re-entering a field after pesticide application, are routinely violated at the workplace. Multiple workers told stories of supervisors (mayordomos) who dismissed the health and safety concerns that workers raised about pesticide exposure and who appeared to violate workplace safety regulations.

There were instances when we felt like vomiting, so we would let the supervisor know...He would tell us that they were spraying the fields, but that the chemicals were not harmful and would not affect us. So he would tell us to start working on the other side of the field. So how were we going to know if it [the spraying] was good or bad? On one occasion, they sprayed a woman co-worker! The tractor passed by and sprayed her!

They never respect the waiting periods...you enter and you can smell it. You say something and the mayordomo says no, no, it's ok.

I know a little bit...but mostly I don't understand how you can be working next to a field that is being sprayed and the mayordomo says it is okay...it is illogical.

Maybe-we can never know [if we have worked in a recently sprayed field]...that they have applied. One cannot know if they respect it or not.

Although the sign said that they had recently sprayed, they told us that this particular chemical didn't cause harm.

Thus, the obstacles to workplace safety on the farm are rooted not in farmworker lack of education or understanding about workplace safety protocols but in the highly vulnerable positionality of farmworkers visa-vis their employers and supervisors, which encourage employer exploitation and employee acquiescence. Compounding the problem is the reality that, in the context of a lack of alternative means of employment, economic precarity and juridical vulnerability, farmworkers perceive forgoing wages as a bigger risk to their well-being than pesticide exposure. This is true even in the case of pregnant farmworkers, who may feel some guilt about working while pregnant but nonetheless feel limited in their capacity to choose not to work.

\section{7. "They work as if they weren't pregnant"}

One of the stated aims of the new Worker Protection Standard is to protect farmworker women and children from the hazards of take-home exposure and pesticide exposure during pregnancy. Ignoring the temporal, spatial, and dosage indeterminacies of epigenetic exposures, these standards do not even go so far as devising special protections for pregnant fieldworkers or admonishing pregnant farmworkers to take particular precautions against exposure in the field. Instead, the updated standard aims to enhance protection simply by expanding knowledge of pesticides and pregnancy health. For women, particularly those that work during their pregnancies, and many of whom are already aware of the risks pesticides pose to their reproductive health, these contradictions of an information based approach add insult to injury.

Women farmworkers, particularly unauthorized, pregnant women, find themselves simultaneously more vulnerable to the harms of pesticide exposure, more responsible for avoiding it, and yet less able to contest its injustice. Of the twenty three women with children that we interviewed, eleven reported that they had 
worked during their pregnancies, some very late (seven to eight months) into their terms. Our interviews with women suggest that women farmworkers frequently work in the fields while they are pregnant and preform the same backbreaking and hazardous jobs as non-pregnant workers. One strawberry worker noted that "they work as if they weren't pregnant", bending low to pick berries and exerting themselves to make adequate income on a piece rate. Another worker, describing the common reality of women working in the fields while pregnant, observed:

There is no consideration for [pregnant women at the work place] because they continue their daily tasks, you know? For example, if she is a strawberry picker and is pregnant, she'll continue picking. It is not like they'll her 'You know what, you are pregnant, you have to do minimal work' ...they continue picking...This past year there was a woman working there that was six months pregnant...they (co-workers) even had a baby shower there...this young woman was still taking off the tarp layer, still working hard...they don't get priority over others...

In keeping with the findings of Flocks et al. (2012) on pregnant farmworkers' perspectives on pesticide use, the women we interviewed who worked during their pregnancies were generally knowledgeable of the potential consequences: they mentioned the possibility of premature births, abortion, birth defects and other outcomes resulting from fetal exposure to pesticides. Several reported knowing of friends or coworkers whose children were born with birth defects or developmental disorders, or who experienced miscarriages. They connected these adverse health outcomes to pesticide exposure in the fields. Yet, our conversations with women suggest that they become aware of the effects of pesticides on pregnancies not through the dissemination of technical information by employers or healthcare officials but primarily through embodied experience with exposure during pregnancy and through experiences within their communities. We also found that farmworker women's heightened vulnerability relative to men is reflected in their perspectives on pesticide use. While both men and women are aware of their potential dangers, women are notably more skeptical of the adequacy of protective measures, and the most vocal and assertive comments about the inadequacy of pesticide exposure came from women who worked during their pregnancies.

When asked about their concerns about exposure during pregnancy, several women referenced negative events that happened to themselves, their relatives, or other women they knew, including miscarriages, premature births, or children born with developmental disabilities. One woman, whose sister-in-law had a child born with Downs Syndrome, described these and other health risks as "part of the work" and said that the community doesn't understand why so many babies are born with medical problems. Asked whether she was concerned about exposure during her pregnancy, one woman worker replied that she was working while a nearby field was being sprayed and later had a miscarriage, along with several other women who had been working with her, and attributed it to pesticides. Reporting a similar experience, one woman discussed observing another group of women in the fields who had miscarriages and attributed it to chemical exposure. Another woman, who gave birth prematurely and attributed it to pesticide exposure during her pregnancy, made this observation about her experience: "Of course there is illness [for children born from women working while pregnant] because you are breathing it in when they are spraying."

Corroborating these accounts of the prevalence of high-risk pregnancies in agricultural communities are the testimonies presented by women from farmworker communities during informational hearings held on the effects of methyl iodide, and comments submitted by farmworkers to the California Department of Pesticide Regulation during the agency's request for public comments on the registration of methyl iodide:

We are farmworkers, we work out of the farm and fields and I'm here representing some coworkers. My husband and I, we've always worked out in the grapes, and I'm here representing some of my coworkers, a majority of them because they have special needs children in the Greenfield area...There are many mothers who are expecting and they work out in the fields and [their babies] are born with disabilities...I think it would be nice for you to think about our community, about us, our children, and our grandchildren who are coming here. Because it was 
said here that we are notified when [pesticides] are sprayed, but they've never taken us into account.

We cannot afford more cancer in our communities, we cannot afford women having abortions that they did not plan for. We cannot afford the risk of having new born children born without hands, legs, [a] backbone [or] without [a] brain. I have seen many of those cases in my life. We don't believe any amount of money should be bigger or more important that having safety and security in our communities and in the fields that we work.

Of the eight women who worked during their pregnancies that responded to an inquiry about their primary source of information about pesticide exposure, six identified their coworkers or word of mouth as their primary source. One woman received information about pesticides and high-risk pregnancies from her participation in the CHAMACOS research, but most did not report access to technical sources of information beyond that provided by their employers, which was not required to include information on the hazards of exposure during pregnancy at the time of this study. Farmworker women, in other words, are already acutely aware of their own biological vulnerability vis-a-vis pesticide exposure and its implications for their pregnancy health, and they are aware not because they have been informed by healthcare providers, employers or other official authorities, but because they have often either experienced or witnessed negative reproductive outcomes in their communities. In that way, the emerging science of environmental epigenetics is providing concrete evidence for something farmworker women already know from experience: that pesticides can and do threaten not only their health, but that of their future progeny.

Farmworker women are also aware that their predicament arises not from a lack of knowledge, but of power on the farm. In addition to an awareness of the adverse effects of exposure on pregnancy health, we found that women farmworkers express heightened doubt relative to their male counterparts about the adequacy of workplace protocols in preventing harmful exposures: $70 \%$ of the women who responded to the interview question "Do you believe protective measures at your workplace are adequate?" answered that their workplace protections were not adequate, in contrast to $71 \%$ of male respondents who said protective measures at their worksites were adequate. These findings confirm those of other studies that observe higher levels of risk perception among female farmworkers, and the tendency of male farmworkers to downplay their assessment of workplace hazards in conformity with a masculine expectation of invulnerability.

One reason that women might be more skeptical of the existing protections is that they apparently receive less protective equipment than their male counterparts. Providing testimony to the head of the California Department of Pesticide Regulation's external review committee during an informational hearing on the registration of methyl iodide, one woman illustrated this potential disparity:

DR. HAMMOND: Could you do me a favor and tell me which kind of mask you use? Point to the picture.

MS. ESPINOZA: None of those. They are just rags, pieces of cloth that we buy.

DR. HAMMOND: You say you buy your own or they gave you?

MS. ESPINOZA: They gave the men the masks, but not to us.

DR. FROINES: They did what?

DR. HAMMOND: They give the men the masks, but not the women.

Through our interviews, we found evidence to support this apparent disparity in access to protective equipment. Most of the women we interviewed who worked during their pregnancies reported that they did not receive protective equipment, such as gloves, from their employers. One of the women who did receive protective equipment said that she nonetheless had to purchase her own gloves, because the plastic ones provided by her employer frequently broke. Another woman commented on her lack of access to adequate protective equipment, explaining that "here in the job they don't give us an explanation — there are companies that give you gloves." 
Of the women we interviewed who were skeptical about the adequacy of their workplace protections, those who worked during their pregnancies were the most vocal and assertive about such inadequacy. All but one of the women that we surveyed who worked during their pregnancies asserted that the current protective measures were inadequate and expressed significant skepticism of their efficacy. One woman, doubting the protectiveness of buffer zones ${ }^{2}$, asserted that they "don't matter if there is wind", an environmental condition that can facilitate the drifting of highly volatile chemicals like soil fumigants which buffer zones are designed to mitigate. Another said she and her coworkers would sometimes cut through recently treated fields when they were running late, arguing that this risky practice "didn't really matter because when they fumigate, the pesticides are already in the air, regardless, so we were already exposed." Yet another woman expressed her doubts about the protectiveness of re-entry restrictions:

We have to wait twenty four hours after a spraying...Sometimes they say it is safe, but some people enter and they get hurt.

Many workers said that they were not concerned about exposure at home or in their communities, but those who did were nearly all women who worked during their pregnancies, suggesting farmworker women have a heightened sense of not only their own vulnerability to pesticide exposure but a sense that their communities are vulnerable as well. Despite their recognition of ubiquitous exposure, several of the women we interviewed still engaged in practices to modulate exposure to themselves and their children. These protective practices included making organic purchases, supplying fruits and vegetables for their children from a home garden, moving their kids to schools farther away from fields and bringing their children inside when they smell pesticides. While undoubtedly inadequate, these also spoke to farmworker women's recognition of the dangers of pesticides regardless of formal information they receive - as well as their internalization of ideas of responsibility for the health outcomes of their progeny.

In short, most of the women who worked during their pregnancies reported nontechnical sources of information as their primary way of learning about exposure; most have either personally experienced or witnessed negative pregnancy outcomes in their communities; and nearly all were knowledgeable of the consequences of pesticide exposure during pregnancy and were skeptical of existing protective measures. And yet, by practicing modest protective measures, they had internalized gendered responsibility for fetal health, even as they recognized the limits of being able to prevent exposure.

Taken together, these findings undermine some critical assumptions of the EPA's updated WPS and cast significant doubt on its ability to meaningfully protect pregnant farmworker women. The key assumption of the standard is that the expanded training content will provide novel information about the hazards of pesticide exposure during pregnancy to farmworker women, and that pregnant women will utilize this information to inform their decision of whether or not to work during their pregnancies. The new standard implies that women can and will choose not to work during their pregnancies, provided they are informed of the risks. But if women are already aware of the hazards and their connection to pesticide exposure, and feel they have little choice but to work anyway, how will including this information in their workplace training meaningfully address their predicament? In the case of most women, we suggest it will not, although it could intensify their feelings of responsibility for the outcomes of their pregnancies.

\section{Conclusion}

The underlying assumption of the EPA's approach to reducing pesticide exposure is that more information will allow farmworkers to make informed decisions about the use of protective equipment, or, when not made available, will make demands on their employers to make such information available. It also assumes that they will complain when other health and safety measures are violated. It follows in the footsteps of right-to-know policy, long a cornerstone of environmental justice demands. But right-to-know assumes full

\footnotetext{
${ }^{2}$ Buffer zones refer to the mandated distance between a pesticide application site and adjacent portions of land. Buffer zone requirements are designed to protect bystanders from pesticide exposure.
} 
protection of the law from retaliation and, actually, given that it has mainly been applied to toxic waste sites, assumes some element of choice in where people might live. These assumptions simply do not hold up for an unauthorized work force, such that workers who complain face not only job loss but the threat of deportation should they complain. For most farmworkers in the US, forgoing work is the bigger risk than pesticide exposure, a fact many of our research subjects corroborated.

For the first time, the new WPS is also aimed toward women who are or may become pregnant. Here the assumption is that pregnant women will, upon being informed of the hazards of pesticide exposure during pregnancy, choose not to work. But given the especially vulnerable position of women farmworkers and the importance of second-earner income to farmworker households, the presence of a meaningful choice is unlikely to exist in practice. At best, pregnant women might adopt more cautious work behaviors to limit their exposure to hazards. But emerging knowledge of the intergenerational effects of pesticide exposure suggests informed caution and the use of personal protective equipment can do little to protect the progeny of pregnant women, given that even low doses of certain pesticides at critical moments of gestation can induce changes in the fetal epigenome that result in health problems and subtle developmental "abnormalities." Our analysis is thus in keeping with a political ecology of the body that both affirms the affective experience of harm as valid knowledge and recognizes that environmental harm is not only a productive of disparate exposure from elsewhere, but involves internal biological processes generated from histories of insult.

Finally, given the biological (as well as structural and social) obstacles women face in protecting themselves and their future progeny, including lacking the same access to protective equipment as men, we find that knowledge is a particularly insufficient condition for protecting reproductive health, but instead just intensifies women's responsibilization. And so, we argue that the EPA's efforts to address neonatal exposure are largely performative nods to an emergent focus environmental epigenetics has placed on the vulnerability of children to environmental hazards rather than concrete measures meant to meaningfully reduce pregnant women's exposure.

Our point, however, is not to diminish the importance of any progress forward. The updated standard is a laudable step toward the inclusion of farmworkers in the occupational right-to-know legislation, from which they have been historically excluded. It is also an important acknowledgement of the specific health and safety concerns of farmworker women, issues that had long been obscured under a gender-neutral protective standard. But much more will be necessary to meaningfully prevent the health-damaging exposures that effect farmworker women and their children, born or unborn. This policy focus should not take the form of limiting pregnant women's access to agricultural occupations - this is not only an illegal and discriminatory practice, but would further endanger pregnant farmworkers, who are often unauthorized, impoverished and lack alternative means of employment by jeopardizing their financial stability. Nor should it necessarily take the form of greater surveillance and disciplining of pregnant farmworker's use of self-protective practices, which this article has suggested are inadequate means of protection from pesticide exposure. Rather, such a focus might consider the new insights epigenetics offers about the vulnerability of pregnant women and developing fetuses for regulatory risk assessment models.

Unfortunately, director Scott Pruitt's departure from the EPA has thus far not meant a wholesale reversal of the course he set on pesticide safety. The Trump Administration's cuts to the agency's enforcement budget in 2018 make hollow an already ineffective enforcement apparatus. Compounding the dangers these cuts pose for farmworker safety will be the effects of an increasingly militarized border and heightened immigration enforcement. In the midst of an escalating crackdown on unauthorized migrants, many farmworkers are potentially subject to deportation. Our interviews with farmworkers, conducted well in advance of Trump's election in 2016, depict a hostile work environment in which workers feel they have little room to contest the frequent exposures, unsafe work practices and pesticide violations for fear of deportation or firing. As the risks of contestation and the political vulnerability of farmworkers grow, the obstacles to agitating for workplace justice only deepen.

So although we have argued that the new Worker Protection Standard is primarily performative in its efforts to protect pregnant women and their progeny from workplace pesticide exposure, the policy direction taken by the EPA to revise the WPS has demonstrated that even gestures toward the health and safety concerns 
of farmworkers and other marginalized groups are preferable to policies that reflect an outright neglect of these communities, as it keeps these issues visible. In this case, something might indeed be better than nothing.

\section{References}

Arcury, T., J. Estrada and S. Quandt. 2010. Overcoming language and literacy barriers in safety and health training of agricultural workers. Journal of Agromedicine 15(3): 236-248.

Bolda, M.P., L. Tourte, J. Murdock and D.A. Sumner. 2010. Sample costs to produce strawberries Central Coast region: Santa Cruz and Monterey Counties. University of California Agriculture and Natural Resources Cooperative Extension and Agricultural Issues Center and UC Davis Department of Agricultural and Resource Economics.

Brennan, K., J. Economos and M. Salerno. 2015. Farmworkers make their voices heard in the call for stronger protections from pesticides. New Solutions: a Journal of Environmental and Occupational Health Policy 25(3): 362-376.

Brown, P. 2007. Toxic exposures: contested illnesses and the environmental health movement. New York: Columbia University Press.

Brownell, P. 2001. Border militarization and the reproduction of Mexican migrant labor. Social Justice 28(2): 69-92.

Cabrera, N. and J. Leckie. 2009. Pesticide risk communication, risk perception, and self-protective behaviors among farmworkers in California's Salinas Valley. Hispanic Journal of Behavioral Sciences 31(2): 258-272.

Calabrese, E.J and L.A Baldwin. 2003. Toxicology rethinks its central belief. Nature 421(6924): 691-692.

Calvert, G.M., J. Karnik, L. Mehler, J. Beckman, B. Morrissey, J. Sievert, R. Barrett, M. Lackovic, L. Mabee, A. Schwartz, Y. Mitchell, and S. Moraga-McHaley. 2008. Acute pesticide poisoning among agricultural workers in the United States, 1998-2005. American Journal of Industrial Medicine 51(12): 883-898.

Carney, M.A. 2014. The biopolitics of food insecurity: towards a critical political ecology of the body in studies of women's transnational migration. Journal of Political Ecology 21(1): 1-18.

Cartwright, E. 2011. Immigrant dreams: legal pathologies and structural vulnerabilities along the immigration continuum. Medical Anthropology 30(5): 475-495.

Castaneda, X. and P. Zavella. 2003. Changing constructions of sexuality and risk: migrant Mexican women farmworkers in California. The Journal of Latin American and Caribbean Anthropology 8(2): 126-150.

Castorina, R., A. Bradman, T.E. McKone, D.B. Barr, M.E. Harnly and B. Eskenazi. 2003. Cumulative organophosphate pesticide exposure and risk assessment among pregnant women living in an agricultural community: a case study from the CHAMACOS Cohort. Environmental Health Perspectives 111(13): 1640-1648.

Crews, D. and J.A. McLachlan. 2006. Epigenetics, evolution, endocrine disruption, health, and disease. Endocrinology 147(6): 4-10.

Diamanti-Kandarakis, E., J.-P. Bourguignon, L.C. Giudice, R. Hauser, G.S. Prins, A.M. Soto, R. Thomas Zoeller and A.C. Gore. 2009. Endocrine-disrupting chemicals: an endocrine society scientific statement. Endocrine Reviews 30(4): 293-342.

Elmore, R.C. and T.A. Arcury. 2001. Pesticide exposure beliefs among Latino farmworkers in North Carolina's Christmas tree industry. American Journal of Industrial Medicine 40(2): 153-160.

Environmental Protection Agency. n.d. Agricultural Worker Protection Standard (WPS). https://www.epa.gov/pesticide-worker-safety/agricultural-worker-protection-standard-wps. Accessed March 25, 2018

Eskenazi, B., A. Bradman, E.A. Gladstone, S. Jaramillo, K. Birch and N. Holland. 2003. CHAMACOS, a longitudinal birth cohort study: lessons from the fields. Journal of Children's Health 1(1): 3-27.

Faulk, C. and D.C. Dolinoy. 2011. Timing is everything: the when and how of environmentally induced changes in the epigenome of animals. Epigenetics 6(7): 791-797. 
Flocks, J., M. Kelley, J. Economos and L. McCauley. 2012. Female farmworkers' perceptions of pesticide exposure and pregnancy health. Journal of Immigrant and Minority Health 14(4): 626-632.

Flocks, J., P. Monaghan, S. Albrecht and A. Bahena. 2007. Florida farmworkers' perceptions and lay knowledge of occupational pesticides. Journal of Community Health 32(3): 181-194.

Galarneau, C. 2013. Farm labor, reproductive justice: migrant women farmworkers in the US. Health and Human Rights 15(1): 144-160.

Galt, R.E. 2013. From homo economicus to complex subjectivities: reconceptualizing farmers as pesticide users. Antipode 45(2): 336-356.

Gore, A.C., J.J. Heindel and R.T Zoeller. 2006. Endocrine disruption for endocrinologists (and others). Endocrinology 147(6): 1-3.

Gravlee, C.C. 2009. How race becomes biology: embodiment of social inequality. American Journal of Physical Anthropology 139(1): 47-57.

Greenhalgh, S. and M. Carney. 2014. Bad biocitizens?: Latinos and the US "obesity epidemic". Human Organization 73(3): 267-276.

Guthman, J. 2011. Weighing in: obesity, food justice, and the limits of capitalism. Oakland: University of California Press.

Guthman, J. 2016. Lives versus livelihoods? Deepening the regulatory debates on soil fumigants in California's strawberry industry. Antipode 49(1): 85-105.

Guthman, J. and S. Brown. 2016. Whose life counts: biopolitics and the 'bright line' of chloropicrin mitigation in California's strawberry industry. Science, Technology, and Human Values 41(3): 461-482.

Guthman, J. and B. Mansfield. 2013. The implications of environmental epigenetics: a new direction for geographic inquiry on health, space, and nature-society relations. Progress in Human Geography 37(4): 486-504.

Harrison, J.L. 2006. Accidents' and invisibilities: scaled discourse and the naturalization of regulatory neglect in California's pesticide drift conflict. Political Geography 25(5): 506-529.

Harrison, J.L. 2008. Abandoned bodies and spaces of sacrifice: pesticide drift activism and the contestation of neoliberal environmental politics in California. Geoforum 39(3): 1197-1214.

Harrison, J.L. 2011. Pesticide drift and the pursuit of environmental justice. Cambridge, MA: MIT Press.

Harrison, J.L and S.E. Lloyd. 2012. Illegality at work: deportability and the productive new era of immigration enforcement. Antipode 44(2): 365-385.

Hausermann, H., P. Tschakert, E.A.H. Smithwick, D. Ferring, R. Amankwah, E. Klutse. J. Hagarty and L. Kromel. 2012. Contours of risk: spatializing human behaviors to understand disease dynamics in changing landscapes. EcoHealth 9(3): 251-255.

Hayes, A.W. 2001. Principles and methods of toxicology. Philadelphia, PA: Taylor and Francis.

Hayes-Conroy, J. and A. Hayes-Conroy. 2013. Veggies and visceralities: a political ecology of food and feeling. Emotion, Space and Society 6: 81-90.

Hernandez, T., S. Gabbard and D. Carroll. 2016. Findings from the National Agricultural Workers Survey (NAWS) 2013-2014: A demographic and employment profile of united states farmworkers. Research Report No. 12. U.S. Department of Labor Employment and Training Administration Office of Policy Development and Research.

Holliday, R. 2006. Epigenetics: a historical overview. Epigenetics 1(2): 76-80.

Holmes, S. 2013. Fresh fruit, broken bodies: migrant farmworkers in the United States. Berkeley: University of California Press.

Horton, S. 2016. They leave their kidneys in the fields: illness, injury, and illegality among U.S. farmworkers. Berkeley: University of California Press.

Horton, S. and J. Barker. 2009. "Stains" on their self-discipline: public health, hygiene, and the disciplining of unauthorized immigrant parents in the nation's internal borderlands. American Ethnologist 36(4): 784798. 
Jablonka, E. and M.J Lamb. 2002. The changing concept of epigenetics. Annals of the New York Academy of Sciences 981(1): 82-96.

Jackson, P. and A.H. Neely. 2015. Triangulating health: toward a practice of a political ecology of health. Progress in Human Geography 39(1): 47-64.

Kasner, E.J., J.M. Keralis, L. Mehler, J. Beckman, J. Bonnar-Prado, S.-J. Lee, B. Diebolt-Brown, P. Mulay, M. Lackovic, J. Waltz, A. Schwartz, Y. Mitchell, S. Moraga-McHaley, R. Roisman, R. Gergely and G.M. Calvert. 2012. Gender differences in acute pesticide-related illnesses and injuries among farmworkers in the United States, 1998-2007. American Journal of Industrial Medicine 55(7): 571-583.

Kegley, S.E., S. Orme and L. Neumeister. 2000. Hooked on poison: pesticide use in California, 1991-1998. Pesticide Action Network.

King, B. 2010. Political ecologies of health. Progress in Human Geography 34(1): 38-55.

Kortenkamp, A. 2007. Ten years of mixing cocktails: a review of combination effects of endocrine-disrupting chemicals. Environmental Health Perspectives 115(Suppl 1): 98-105.

Krimsky, S. 2000. Hormonal chaos: the scientific and social origins of the environmental endocrine hypothesis. Baltimore: John Hopkins University Press.

Langston, N. 2010. Toxic bodies: hormone disruptors and the legacy of DES. New Haven: Yale University Press.

London, L., S. De Grosbois, C. Wesseling, S. Kisting, H.A. Rother and D. Mergler. 2002. Pesticide usage and health consequences for women in developing countries: out of sight out of mind? International Journal of Occupational and Environmental Health 8(1): 46-59.

McIntyre, M. and H.J Nast. 2011. Bio (necro) polis: Marx, surplus populations, and the spatial dialectics of reproduction and "race". Antipode 43 (5): 1465-1488.

Mansfield, B. and J. Guthman. 2015. Epigenetic life: biological plasticity, abnormality, and new configurations of race and reproduction. Cultural Geographies 22(1): 3-20.

Melamed, J. 2015. Racial capitalism. Critical Ethnic Studies 1(1): 76-85.

Minkoff-Zern, L. 2014. Hunger amidst plenty: farmworker food insecurity and coping strategies in California. Local Environment 19(2): 204-219.

Minkoff-Zern, L. and M. Carney. 2015. Latino im/migrants, "dietary health" and social exclusion. Food, Culture and Society 18(3): 463-480.

Mitchell, D. 2007. Work, struggle, death, and geographies of justice: the transformation of landscape in and beyond California's Imperial Valley. Landscape Research 32(5): 559-577.

Mu, X. and G.A. Leblanc. 2004. Synergistic interaction of endocrine-disrupting chemicals: model development using an ecdysone receptor antagonist and a hormone synthesis inhibitor. Environmental Toxicology and Chemistry 23(4): 1085-1091.

Nash, L. 2004. The fruits of ill-health: pesticides and workers' bodies in post-World War II California. Osiris 19(1): 203-219.

Nash, L. 2006. Inescapable ecologies: a history of environment, disease and knowledge. Berkeley: University of California Press.

Neely, A.H. 2015. Internal ecologies and the limits of local biologies: a political ecology of tuberculosis in the time of AIDS. Annals of the Association of American Geographers 105(4): 791-805.

Nevins, J. 2001. Operation gatekeeper: the rise of the" illegal alien" and the making of the US-Mexico boundary. London: Routledge.

Nyantakyi-Frimpong, H., G. Arku, and D.K.B Inkoom. 2016. Urban agriculture and political ecology of health in municipal Ashaiman, Ghana. Geoforum 72: 38-48.

Pulido, L. 1996. Environmentalism and economic justice: two Chicano struggles in the Southwest. Tucson: University of Arizona Press.

Pulido, L. 2017. Geographies of race and ethnicity II: environmental racism, racial capitalism and statesanctioned violence. Progress in Human Geography 41(4): 524-533. 
Pulido, L. and D. Peña. 1998. Environmentalism and positionality: the early pesticide campaign of the United Farm Workers' organizing committee, 1965-71. Race, Gender and Class 6(1): 33-50.

Robbins, P. 2007. Lawn people: how grasses, weeds, and chemicals make us who we are. Philadelphia: Temple University Press.

Salvatore, A.L., A. Bradman, R. Castorina, J. Camacho, J. López, D. Barr, J. Snyder, N.P. Jewell, and B. Eskenazi. 2008. Occupational behaviors and farmworkers' pesticide exposure: findings from a study in Monterey County, California. American Journal of Industrial Medicine 51(10): 782-794.

Saxton, D.I. 2015. Strawberry fields as extreme environments: the ecobiopolitics of farmworker health. Medical Anthropology 34(2): 166-183.

Sexsmith, K. 2016. Exit, voice, constrained loyalty, and entrapment: migrant farmworkers and the expression of discontent on New York dairy farms. Citizenship Studies 20(3-4): 311-325.

Snipes, S.A., B. Thompson, K. O'Connor, B. Shell-Duncan, D. King, A.P. Herrera and B. Navarro. 2009. Pesticides protect the fruit, but not the people: using community-based ethnography to understand farmworker pesticide-exposure risks. American Journal of Public Health 99(S3): S616-S621.

Thayer, Z.M. and C.W. Kuzawa. 2011. Biological memories of past environments: epigenetic pathways to health disparities. Epigenetics 6(7): 798-803.

Thomas, R.J. 1992. Citizenship, gender, and work: social organization of industrial agriculture. Berkeley: University of California Press.

Wargo, J. 2009. Green intelligence: creating environments that protect human health. New Haven: Yale University Press.

Waugh, I.M. 2010. Examining the sexual harassment experiences of Mexican immigrant farmworking women. Violence Against Women 16(3): 237-261.

Willen, S. 2007. Toward a critical phenomenology of "illegality": state power, criminalization, and abjectivity among unauthorized migrant workers in Tel Aviv, Israel. International Migration 45(3): 8-38.

Yates, M. 2011. The human-as-waste, the labor theory of value and disposability in contemporary capitalism. Antipode 43(5): 1679-1695

Young, J.G., B. Eskenazi, E.A. Gladstone, A. Bradman, L. Pedersen, C. Johnson, D.B. Barr, C.E. Furlong and N.T. Holland. 2005. Association between in utero organophosphate pesticide exposure and abnormal reflexes in neonates. NeuroToxicology 26(2): 199-209. 